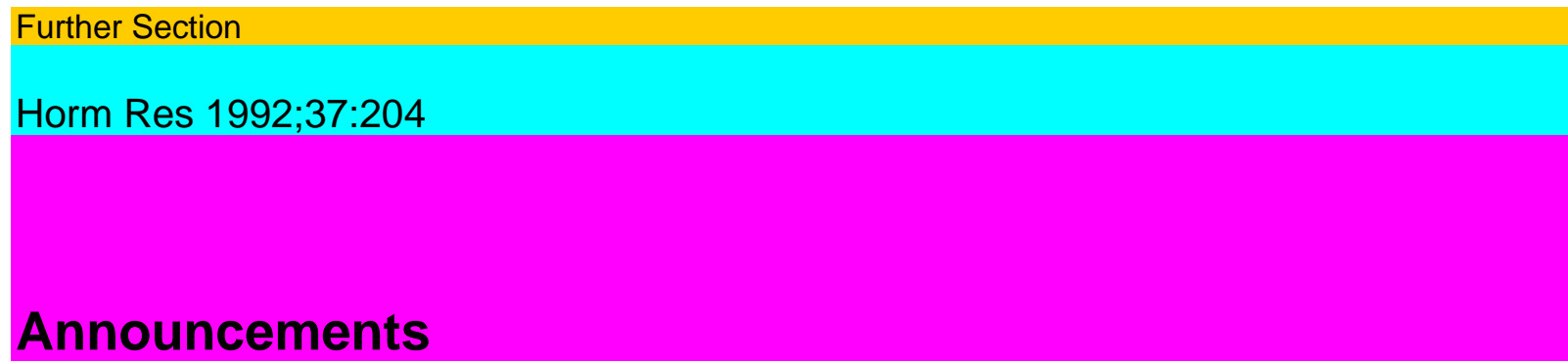

\title{
First Announcement
}

Trace Elements and Free Radicals in Oxidative

Diseases

4th International Meeting on Trace Elements in Medicine

and Biology

April 5-9, 1993, Chamonix, France

Main topics

Relations Between Trace Elements and Free Radicals Trace elements: zinc, selenium, iron,

copper Free radicals, Peroxidation, DNA, Lipid, Cancer, Inflammation, Aging, Atherosclerosis, Immunity

Official Language English

Simultaneous translation French - English

Organized by

Society for Free Radical Research (SFRR), and Société Francophone d'Etude et de Recherche sur les Elements Trace Essentiels (SFERETE)

Local organizer

Club d'Etude sur les Radicaux Libres (CERLIB)

Registration, Information

Professeur Alain Favier

Madame Arlette Alcaraz

Laboratoire de Biochimie C

Hôpital A. Michallon

B.P.217X

F-38043 Grenoble Cédex 09 (France)

Tél.: (33) 76765407

Fax: (33) 76426644

International Meeting on Sex Hormones and Antihormones in Endocrine-Dependent Pathology:

Basic and Clinical Aspects

September 26-30, 1993, Milano, Italy

An International Symposium on 'Sex Hormones and Antihormones in Endocrine-Dependent

Pathology: Basic and Clinical Aspects' will be held in Milano, Italy (September 26-30), in 1993.

The meeting will be planned by an International Scientific Committee formed by:

E.E. Baulieu (France)

M. Baum (UK)

L. Denis (Belgium)

J. Geller (USA)

K. Griffiths (UK)

O. Isaksson (Sweden)

M. Lippman (USA) 
L.R. Malinak (USA)

M. Motta (Italy; chairman)

C.G. Rivier (USA)

R.J. Santen (USA)

F. Schroeder (The Netherlands)

M. Serio (Italy)

The program will include invited lectures as well as sessions of free communications and/or poster presentations on the following topics:

the normal and pathological prostate and breast: morphological, biochemical and hormonal parameters;

new therapeutic approaches in prostate and breast tumors (animal and human studies);

gynecological disorders and their hormonal therapy.

For any information regarding the program, please contact the Scientific Secretaries.

Scientific Secretaries M. Motta and M. Serio Department of Endocrinology University of Milano 9, Via Balzaretti 1-20133 Milano (Italy)

Tel. 02-29406576 Fax 02-29404927

204 